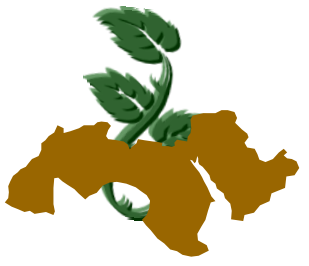

\title{
MICROBIAL PRODUCTION OF THERMOALKALIPHILIC ENZYMES FROM EL-KHORMA GOVERNORATE FOR APPLICATION IN BIODETERGENT TECHNOLOGY
}

\author{
Bayoumi1a); R.A.; H.M. Atta'; M.H. El-Sehrawey $^{2}$; Sh.M. Selim ${ }^{1}$ \\ And A. El-Hemiany ${ }^{3}$ \\ 1- Taif University, Taif, Saudi Arabia, Faculty of Science and Education, Biotechnology Dept., \\ (El-Khorma Branch) \\ a) Corresponding author: Reda Ahmed Bayoumi, Biotechnology Dept., Faculty of Science and \\ Education, Taif Univ., (El-khorma Branch), KSA. \\ E-mail: redaelbayoumi@yahoo.com \\ 2- Taif University, Taif, Saudi Arabia, Faculty of Science, Biotechnology Dept. \\ 3- Taif University, Faculty of Biomedical Science, Taif, Saudi Arabia, (Turaba branch)
}

Keywords: Thermostable, Alkaliphilic, Protease, Biodetergent, Bacillus licheniformis

\section{ABSTRACT}

Detergents are an undetectable source of pollution, which hidden in most of our daily activities. Detergents could cause harmful effects before they are completely degraded. It is wise to reduce the amount of detergents that usually used by invention new bio-friendly formula contains efficient enzymes such as protease. Screening studies were carried out for one hundred and fifty bacterial isolates with respect to their ability to produce protease(s), after growing on slaughter house wastes (SHW) isolated from El-Khorma governorate,Taif, Kingdom of Saudi Arabia (KSA) at $55^{\circ} \mathrm{C}$, and $\mathrm{pH} 9$. The most potent thermophilic bacterial isolate concerning of alkaline thermostable protease(s) production was identified as Bacillus licheniformis EGT50. Alkaline thermostable proteases productivity by the most potent bacterial isolate was affected by substrate concentrations (solid substrate), carbon source, nitrogen source, amino acid supplements, incubation temperature, incubation period, and inoculum size. Maximum both enzymes production by $B$. licheniformis EGT50 was obtained on SHW concentrations, $7.5 \%$; galactose; diammonium hydrogen phosphate; arginine at $55^{\circ} \mathrm{C}$ for $72 \mathrm{~h}$. when inoculated by $0.5 \mathrm{ml}$. The protease production under all optimal conditions was increased many folds from 563.68 to $17825 \mathrm{U} / \mathrm{ml}$ (31 fold). The purification fold of $B$. licheniformis
EGT50 alkaline thermostable protease increased to 394.7 after applying Sephadex G200 column chromatography techniques. The enzyme productivity of protease has been determined and the result proved the possibility to use the crude and purified enzymes in biodetergent technology.

\section{INTRODUCTION}

Enzymes play a significant role in our life. Their existence had been associated with the history of ancient civilizations. Enzymes from plant and microorganisms had been used in brewing, baking, alcohol production, cheese, vinegar making..... etc. The uses of enzymes were variable ranging from just making wine or bread to producing complicated fermentations processes. Technical enzymes represent 1 billion USD in 1999 (Schäfer et al 2005; Kumar et al 2009 and Haddar et al 2010). Part of these enzymes is the thermostable enzymes, which are better, suited for harsh industrial processes and constitute more than $65 \%$ of the global market (Leuschner and Antranikan, 1995; Rao et al 1998; Gupta et al 2002; Beg and Gupta, 2003; Amara et al 2009; Mário et al 2009; Akanbi et al 2010; Haddar et al 2010 and Eltayib et al 2010).

Protease constitutes one of the most important groups of industrial enzymes, accounting for about $60 \%$ of the total enzyme market (Nunes and Martins, 2001). Protease are of commercial value and find multiple applications in various industrial sectors. Proteases are widely used in detergents, food 
and leather tanning industries (Abidi et al 2008). Alkaliphilic Bacillus are considerable as prolific producers of alkaline proteases, which exhibit significant activity and stability at high $\mathrm{pH}$ and temperatures (Yang et al 2000; Christiansen and Nielsen, 2002; Joo et al 2003 \& 2004 and Kumar et al 2009). Enzymes have many applications especially in paper industry, detergents, drugs, degradation of different wastes, textile, food, pharmaceutical, leather, degumming of silk goods, manufacture of liquid glue, cosmetics, meat tenderization, cheese production, growth promoters ...etc (Schäfer et al 2005; Cowan,1996 and Haddar et al 2010). Meanwhile one of the most important and profitable applications for enzymes is in detergents. The first use of enzymes in detergents occurred in 1913 when Röhm and Haas introduced crude trypsin into their detergent. Burnus based on a German patent issued to Otto Röhm (1913) (Schafer et al 2005). To provide desirable benefits, enzymes must be stable and function well in the presence of a variety of potentially unfriendly detergent ingredients (e.g., anionic/ nonionic/ cationic surfactants, chelants, builders, polymers, bleaches) and in various forms of detergent products (i.e., liquids and powders) (Schäfer et al 2005; Amara et al 2009; Mário et al 2009 and Akanbi et al 2010).

In present study, isolation, purification, and identification of thermophilic bacterial isolates from El-khorma governorate, Kingdom of Saudi Arabia; production of an alkaline thermostable protease from $B$. licheniformis EGT50 and optimization of the alkaline thermostable protease production parameters for potential use as a detergent industry.

\section{MATERIALS AND METHODS}

1- Microorganisms: An alkaliphilic $B$. licheniformis EGT50 strain, which produces proteases, was originally isolated from different desert soil samples collected from different localities of El-khorma governorate, Taif, kingdom of Saudi Arabia. The most potent thermoalkaliphilic strain found to be capable of producing extracellular alkaline protease was identified and the criteria laid down in Bergey's Manual of Systematic Bacteriology (Sneath, 1986; and Schallmey et al 2004).

2- Construction of standard enzyme and protein curves: A stock solution of $\left(50^{\prime} 000 \mu \mathrm{g} / \mathrm{ml}\right)$ purified protease enzyme supplied by Sigma chemicals $\mathrm{Co}$. was prepared in Tris- $\mathrm{HCl}$ buffer $(0.2 \mathrm{M})$ at $\mathrm{pH} 9$, where descending dilutions were prepared. After preparing the required dilutions for protease, only $0.1 \mathrm{ml}$ of each dilution was transferred to each well in the gelatin-substrate medium using gelatin clearing zone (GCZ) technique. The obtained standard curve was used for estimating the enzymes activities in terms of $\mu \mathrm{g} / \mathrm{ml}$ and then translated into units $(U)$. One unit is defined as the amount of enzyme protein $(\mathrm{mg})$ required to exert one unit of clearing zone $(\mathrm{mm})$ in one unit time under all the specified conditions of enzyme assay (clearing zone technique). The total protein determination was made according to the method of Lowry et al (1951) using bovine serum albumin as a standard protein

3- Production medium: Alkaline thermostable protease production was determined by applying a modified basal medium given by Vincent (1970), containing of the following ingredients $(\mathrm{g} / \mathrm{l})$ : SHW, 10; $\mathrm{NaCl}, 6$; $\left(\mathrm{NH}_{4}\right)_{2} \mathrm{SO}_{4}, 1$; yeast extract, 1; $\mathrm{KH}_{2} \mathrm{PO}_{4}, 0.5 ; \mathrm{MgSO}_{4} 7 \mathrm{H}_{2} \mathrm{O}, 0.1 ; \mathrm{CaCl}_{2} 6 \mathrm{H}_{2} \mathrm{O}, 0.1$; $\mathrm{FeSO}_{4} 7 \mathrm{H}_{2} \mathrm{O}$. All ingredients were dissolved in distilled water and completed up to one liter. The initial $\mathrm{pH}$ of the culture medium was adjusted at 9 .

4- Protease(s) assay medium for gelatin clearing zone (GCZ) technique: This medium was devoted to gelatin clearing zone (GCZ) technique according to Ammar et al (1991). The assay plates contained $1 \%$ gelatin and $1.5 \%$ agar for solidification, to be dissolved in $100 \mathrm{ml}$ of Tris- $\mathrm{HCl}$ buffer ( $\mathrm{pH}$ 9). At the end of incubation period, protease(s) activity was detected by flooding each plate with $10 \mathrm{ml}$ freshly prepared acid mercuric chloride solution (Barrow and Feltham, 1993). Mean diameters of clearing zones were measured, and taken as indication for proteolytic activities. The standard errors of mean values were less than $3 \%$.

5-Solid state fermentation (SSF): Five grams of SHW were introduced moistened with $5 \mathrm{ml}$ of production medium in $250 \mathrm{ml}$ Erlenmeyer flask, and autoclaved at $15 \mathrm{psi}$ for $20 \mathrm{~min}$, was taken as the basal medium for SSF studies was adjusted at $\mathrm{pH}$ of 9.0. Medium was left to cool, inoculated with 0.5 $\mathrm{ml}$ of the inoculum (A 600;0.8), having $1.5 \times 10^{6}$ cells $/ \mathrm{ml}$ in case of $B$. licheniformis EGT50 from 12 h. old shake culture and incubated at $65^{\circ} \mathrm{C}$. Visual observations regarding growth were made each day and the SHW was mixed with $10 \mathrm{ml}$ of tap water, and filtered through a metallic sieve. The extracted filtrate was centrifuged $\left(10^{\prime} 000 \mathrm{xg} ; 4^{\circ} \mathrm{C}\right)$ for $15 \mathrm{~min}$ and cell free filtrate was used as the source of crude alkaline thermostable protease. 
6- Optimization of fermentation conditions for alkaline thermostable protease production: Protease production was optimized under SSF on SHW, unless otherwise stated, by altering various physicochemical conditions. Effect of different temperatures, $\mathrm{pH}$ values, different substrate concentrations, various supplements on the alkaline thermostable protease production by adding different carbon sources $(1 \% \mathrm{w} / \mathrm{w})$, nitrogen sources, inoculum sizes and incubation periods were carried out by allowing the $B$. licheniformis EGT 50 strain to grow on SHW and incubated at different incubation periods at $55^{\circ} \mathrm{C}$ at $\mathrm{pH} 9$.

7- Protease production by $B$. licheniformis EGT50: B. licheniformis EGT50 was allowed to grow under the optimal static natural substrate under solid state fermentation conditions on slaughter house wastes for protease(s) production. The optimum protease(s) production medium contained $(\mathrm{g} / \mathrm{l}, \mathrm{w} / \mathrm{v}), 10 \mathrm{~g}$ of slaughter houses wastes per flask of $1000 \mathrm{ml}$ capacity were used and supplemented by $20 \mathrm{ml}$ of production medium, which contained (g/l, w/v): NaCl, 6; $\mathrm{KH}_{2} \mathrm{PO}_{4}, 0.5$; $\mathrm{MgSO}_{4} 7 \mathrm{H}_{2} \mathrm{O}, 0.1 ; \mathrm{CaCl}_{2} 6 \mathrm{H}_{2} \mathrm{O}, 0.1$; yeast extract, 1 in addition to galactose, ammonium dihydrogen phosphate, and arginine, $\mathrm{pH}$ was adjusted at 9, and inoculated with bacterial suspension and incubated at $55^{\circ} \mathrm{C}$ for $72 \mathrm{~h}$.

8- Enzyme purification: To the cell free supernatant, ammonium sulphate was added up to $80 \%$ saturation and centrifuged (15'000 rpm for $15 \mathrm{~min}$ ) after $2 \mathrm{~h}$ of incubation at $4^{\circ} \mathrm{C}$. The precipitate was dissolved in a minimum amount of Tris- $\mathrm{HCl}$ buffer (0.2M) at $\mathrm{pH} 9$, dialyzed overnight against the same buffer and retained for further purification steps by sephadex G200. After dialysis, the supernatant, containing enzyme protein, was applied to a sephadex G200 (particle size 200M) column (50 $\mathrm{cm} \times 2.5 \mathrm{~cm}$ ) pre-equilibrated with Tris- $\mathrm{HCl}$ buffer $(0.2 \mathrm{M})$ at $\mathrm{pH}$ 9. Fractions $(5 \mathrm{ml}$ each) were collected at the flow rate of $20 \mathrm{ml} / \mathrm{h}$ and assessed for enzyme activity.

\section{RESULTS AND DISCUSSION}

Enzymes have long been of interest to the detergent industry for their ability to aid in the removal of proteinaceous stains and to deliver unique benefits that cannot otherwise be obtained with conventional detergent technologies. Due to potential usefulness of alkaline thermostable protease in bio-detergent industry, the development of methods for cheaper production of enzyme is very im- portant. SSF holds tremendous potential for the production of enzymes and it can be used of special interest in these processes where the crude fermented product may be used directly as enzyme source (Tongerdy, 1998; Pandey et al 1999 a\&b; Haddar et al 2010 and Eltayib et al 2010).

Out of one hundred and fifty thermophilic bacterial isolates was found that only 20 isolates gave higher protease productivity. Data recorded in Table (1) showed the ability of twenty bacterial isolates selected from the qualitative screening to attack SHW for protease(s) production. It was found that bacterial isolates number EGT50, EGT95, EGT106 and EGT147 gave the highest proteolytic productivities 28; 22.16; 20.5 and 20.8 $\mathrm{mm}$ respectively. From the previous results, bacterial isolate viz. EGT50 was selected as the most potent bacterial isolates for their potentiality to highest production of alkaline thermostable protease.

\subsection{Optimization of solid state fermentation (SSF)}

There are several factors, affecting SSF processes for protease production. Among these, selection of a suitable strain, and selection of process parameters (Temperature, $\mathrm{pH}$ values, substrate concentration, nitrogen sources and incubation periods) are crucial (Pandey et al 2000). While efforts largely continued to exploit filamentous fungi and yeast for the production of various products, attempts have also been made to explore the possibilities of using bacterial strains in SSF systems (Babu and Satyanarayana, 1995). The most potent producer bacterial strain viz. $B$. licheniformis EGT50 for concerning alkaline thermostable protease, used in present manuscript was capable of growing at $55^{\circ} \mathrm{C}$ and $\mathrm{pH} 9$.

From industrial point of view, in order to get production of low cost of enzymes, this bacterial isolate under study was allowed to grown on natural substances such as SHW under SSF conditions, However, the selection of the previously mentioned substrate for the process of enzymes biosynthesis was based on the following factors viz (i) they represent the most cheapest agro-industrial wastes in Taif; (ii) they are available at any time of the year; (iii) Their storage represents no problem in comparison with other substrates and (iv) they resist any drastic effect due to the exposure to other environmental conditions e.g. temperature, variation in the weather from season to season and or from day to night. 
Table 1. Screening program of protease production by the most potent thermophilic bacterial isolates by growing on $\mathrm{SHW}$ at $55^{\circ} \mathrm{C}$ for $48 \mathrm{~h}$. using $\mathrm{GCZ}$ technique

\begin{tabular}{|c|c|c|c|c|c|}
\hline No. & $\begin{array}{c}\text { Code } \\
\text { number }\end{array}$ & $\begin{array}{c}\text { Proteases }(\mathbf{s}) \text { production } \\
\text { GCZ technique }(\mathbf{m m}) .\end{array}$ & No. & $\begin{array}{c}\text { Code } \\
\text { number }\end{array}$ & $\begin{array}{c}\text { Protease(s) production } \\
\text { GCZ technique (mm). }\end{array}$ \\
\hline 1 & EGT15 & $20.0 \pm 0.13$ & 11 & EGT 78 & $21.8 \pm 0.0$ \\
2 & EGT 38 & $18.5 \pm 0.0$ & 12 & EGT 80 & $18.0 \pm 0.47$ \\
3 & EGT 42 & $19.5 \pm 0.0$ & 13 & EGT 89 & $20.6 \pm 0.0$ \\
4 & EGT 47 & $22.6 \pm 0.0$ & 14 & EGT 90 & $18.16 \pm 0.0$ \\
5 & EGT 50 & $28.0 \pm 0.0$ & 15 & EGT 95 & $22.16 \pm 0.52$ \\
6 & EGT 60 & $20.0 \pm 0.1$ & 16 & EGT 106 & $20.5 \pm 0.49$ \\
7 & EGT 64 & $20.0 \pm 0.0$ & 17 & EGT 108 & $17.5 \pm 0.0$ \\
8 & EGT 70 & $19.16 \pm 0.0$ & 18 & EGT 110 & $19.0 \pm 0.0$ \\
9 & EGT 71 & $20.0 \pm 0.0$ & 19 & EGT 141 & $20.3 \pm 0.58$ \\
10 & EGT 72 & $18.6 \pm 0.0$ & 20 & EGT 147 & $20.8 \pm 0.0$ \\
\hline
\end{tabular}

Interestingly slaughter house wastes are an important pollutant factor for the environment, many pathogenic microorganisms can grow on it, this may cause many diseases for man and animals, thus its use for enzymes production help in prevention disease distribution. Therefore, the purpose of the present work is to determine the best factors controlling the enzyme(s) productivities by $B$. licheniformis EGT50. On the other hand, the economic feasibility of the microbial enzymes production for its application generally depends on the cost of its production processes. In order to obtain high and commercially viable yields of alkaline-thermostable enzymes, it was essential to optimize the fermentation medium used for bacterial growth and enzymes production from the most potent thermophilic Bacillus strain. Optimal parameters of the alkalinethermostable enzymes biosynthesis from microbial origin, varied greatly, with the variation of the producing strain, environmental, and nutritional conditions.

The maximum protease(s) productivity was attained at $55^{\circ} \mathrm{C}$ in the presence of SHW viz. $563.68 \mathrm{U} / \mathrm{ml}$ for $B$. licheniformis EGT50 bacterial strain (Fig. 1).

$\mathrm{pH}$ is among the other most important factors for any fermentation process and dependent on the type of the moistening agent used in the medium. Each microorganism possesses a $\mathrm{pH}$ range for its growth and activity with an optimal value in between the range. The $\mathrm{pH}$ of the culture medium plays a critical role for the optimal physiological performance of the microbial cells and the transport of various nutrient components a cross the cell membrane aiming at maximizing the alkaline enzymes yields. Thus, the $\mathrm{pH}$ of the fermentation medium has a marked effect on the cell growth and enzyme production (Kumar et al 1999\&2004; Kumar et al 2009 and Mário et al 2009). Furthermore the optimal $\mathrm{pH}$ values may be affected by the incubation temperature in many thermophiles. However, it was not surprising to find that, not only the incubation temperature was affecting the optimal $\mathrm{pH}$ value, but also many factors in the environment may change it i.e. secretion of alkaline solutions like ammonia or acids like oxalic acid in the medium (St. Leger et al 1999), incubation period, growth changes in medium, growth factors supply, the different minerals and nitrogen source. The variation in the $\mathrm{pH}$ value for protease production was affected by strain or species difference. Moreover, several workers indicated that, the variations in the $\mathrm{pH}$ value for proteases production even within the same bacterial species owing to the difference in method applied and different environmental conditions. The optimum initial $\mathrm{pH}$ value capable of promoting protease(s) production by $B$. licheniformis EGT50 was found to be at the value of 9.0 since the enzyme(s) yields reached up to $447.74 \mathrm{U} / \mathrm{ml}$ (Table 2). The maximum protease(s) 


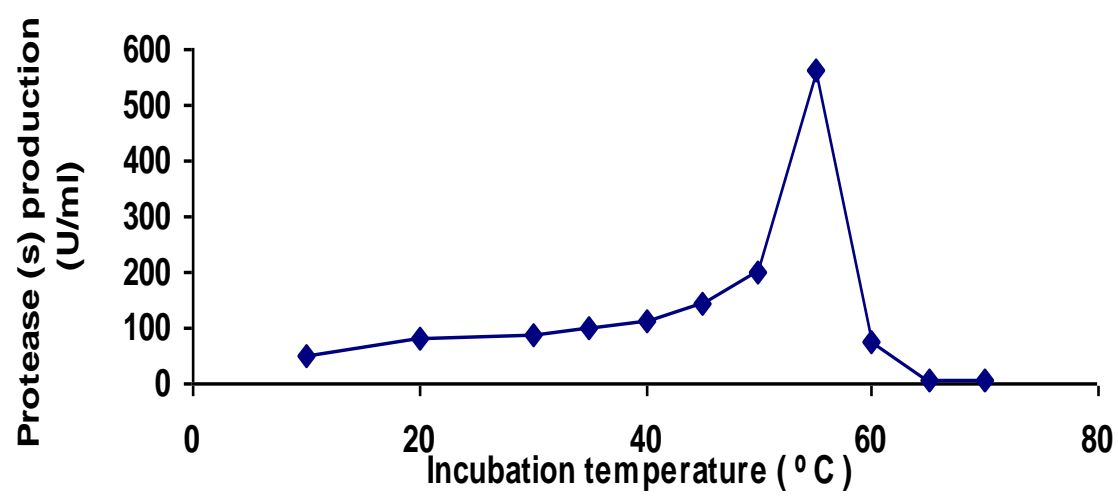

Fig. 1. Effect of different incubation temperatures on protease(s) productivity by $B$. licheniformis EGT50.

Table 2. Relation of different incubation temperatures, $\mathrm{pH}$ and substrate concentration to protease(s) production by $B$. licheniformis B-50 allowed to grow on SHBM under Submerged fermentation (SmF) conditions

\begin{tabular}{|c|c|c|c|c|c|}
\hline $\begin{array}{c}\text { Incubation } \\
\text { temperature } \\
\left({ }^{\mathbf{}} \mathbf{C}\right)\end{array}$ & $\begin{array}{c}\text { Protease(s) } \\
\text { production } \\
\text { (unit/ml) }\end{array}$ & $\begin{array}{c}\text { Initial } \mathbf{~ p H} \\
\text { value }\end{array}$ & $\begin{array}{c}\text { Protease(s) } \\
\text { production } \\
\text { (unit/ml) }\end{array}$ & $\begin{array}{c}\text { Substrate } \\
\text { concentration } \\
\text { (g/flask) }\end{array}$ & $\begin{array}{c}\text { Protease(s) } \\
\text { production } \\
\text { (unit/ml) }\end{array}$ \\
\hline 10 & $50.23 \pm 2.08$ & 3 & 0.0 & 0.05 & $2.82 \pm 0.9$ \\
20 & $79.62 \pm 1.5$ & 5 & $10.02 \pm 0.0$ & 0.1 & $13.36 \pm 0.52$ \\
30 & $89.33 \pm .38$ & 6 & $17.82 \pm 0.0$ & 0.2 & $44.77 \pm 0.49$ \\
35 & $100.2 \pm 0.0$ & 7 & $100.23 \pm 0.0$ & 0.5 & $89.33 \pm 0.7$ \\
40 & $112.47 \pm 3.09$ & 7.5 & $178.25 \pm 0.0$ & 1.0 & $188.8 \pm 0.38$ \\
45 & $141.59 \pm 0.98$ & 8 & $316.98 \pm 0.0$ & 1.5 & $316.98 \pm 0.6$ \\
50 & $200.0 \pm 2.3$ & 8.5 & $422.69 \pm 0.0$ & & \\
55 & $563.68 \pm 2.0$ & 9 & $447.74 \pm 1.04$ & & \\
60 & $75.16 \pm 1.4$ & 9.5 & $10.02 \pm 0.0$ & & \\
65 & $4.23 \pm .52$ & 10 & $5.64 \pm 0.0$ & & \\
70 & $3.16 \pm 0.0$ & & & & \\
\hline
\end{tabular}

productivity was reached up to $316.98 \mathrm{u} / \mathrm{ml}$ with SHW concentration of $1.5 \mathrm{~g} / 100 \mathrm{ml}$ produced by $B$. licheniformis EGT50 by incubation at $55^{\circ} \mathrm{C}$ for 48 h. These results mean that, protease(s) biosynthesis depends not only on the substrate concentration but also on the producing strain. B. licheniformis B42 was able to utilize D (+) galactose which increased protease(s) production on SHW basal medium (Table 3 ).

Ammonium di-hydrogen phosphate was considered to be the best induced for the highest protease productivity by $B$. licheniformis EGT50 where the enzymes productivity reached up to $2377 \mathrm{U} / \mathrm{ml}$ with SHW (Table 4). The maximum protease(s) productivity was reached up to $1888.12 \mathrm{U} / \mathrm{ml}$ at inoculum size of $0.5 \mathrm{ml} /$ flask by $B$. licheniformis EGT50.
The most potent bacterial strain viz. B. licheniformis $\mathrm{B} 50$ exhibited its maximum ability to biosynthesis protease(s) with $72 \mathrm{~h}$ incubation period, since the productivity reached up to $3556.5 \mathrm{U} / \mathrm{ml}$ (Table 5).

The maximum protease(s) production reached up to $25178.5 \mathrm{U} / \mathrm{ml}$ by introducing thiamin into the production medium, this followed by L-Ascorbic acid and nicotinic acid which reached up to $23770.0 \mathrm{U} / \mathrm{ml}$ by $B$. licheniformis EGT50.

The alkaline thermostable protease(s) productivity reached its maximal value $2377.0 \mathrm{U} / \mathrm{ml}$ by the addition of L-arginine to SHW production medium by $B$. licheniformis EGT50. Also, DL-serine, and Lglutamine exerted high stimulatory effect on protease production by the same bacterial strain (Table 6). 
Table 3. Relation of application of different carbon sources to protease(s) productivity by $B$. Iicheniformis B-50 allowed to grow under SmF conditions at 55C

\begin{tabular}{|c|c|c|c|}
\hline Carbon source & $\begin{array}{c}\text { Protease }(\mathbf{s}) \\
\text { production }(\mathbf{U} / \mathbf{m l})\end{array}$ & Carbon source & $\begin{array}{c}\text { Protease(s) } \\
\text { production }(\mathbf{U} / \mathbf{m l})\end{array}$ \\
\hline Control & $316.98 \pm 0.6$ & Disaccharides & $563.68 \pm 0.0$ \\
Monosaccharides & $1002.37 \pm 0.0$ & Maltose & $1002.37 \pm 0.0$ \\
Ribose & $316.98 \pm 0.6$ & Sucrose & $563.68 \pm 0.0$ \\
D(+) Xylose & $316.98 \pm 0.0$ & Cellobiose & $1782.5 \pm 0.0$ \\
D(-) Arabinose & $1782.5 \pm 0.0$ & Trisaccharides & \\
D(-) Glucose & $1957.6 \pm 0.38$ & Raffinose & $56.36 \pm 0.16$ \\
D(+) Galactose & $563.68 \pm 0.3$ & Solysaccharides & $178.25 \pm 0.0$ \\
D(+) Mannose & $1002.37 \pm 0.0$ & Cellulose & $1002.37 \pm 0.0$ \\
D(-) Fructose & $1002.37 \pm 0.0$ & Dextrin & $1869.7 \pm 0.11$ \\
Rhamnose & $1002.37 \pm 0.0$ & Inuline & $1782.5 \pm 0.0$ \\
Trehalose & & Polyhydric alcohol & \\
Disaccharides & $316.98 \pm 0.28$ & Mannitol & $563.68 \pm 0.0$ \\
Lactose & &
\end{tabular}

Table 4. Relation of application of different nitrogen sources to protease(s) productivity by B. licheniformis EGT50 allowed to grow on SHW under SSF conditions at 55C

\begin{tabular}{|l|c|}
\hline \multicolumn{1}{|c|}{ Nitrogen source } & Protease(s) production (U/ml). \\
\hline Urea & $1782.0 \pm 1.04$ \\
Sodium nitrate & $422.69 \pm 0.52$ \\
Potassium nitrate & $422.69 \pm 0.52$ \\
Peptone & $1002.37 \pm 0.0$ \\
Magnesium nitrate & $1002.37 \pm 0.0$ \\
Control & $1957.6 \pm 0.0$ \\
Ammonium sulphate & $1336.69 \pm 0.52$ \\
Ammonium nitrate & $1336.89 \pm 0.52$ \\
Ammonium molybdate & $316.98 \pm 1.04$ \\
Ammonium dihydrogen phosphate & $2377 \pm 0.52$ \\
Ammonium chloride & $1336.69 \pm 0.52$ \\
Ammonium acetate & $1002.37 \pm 0.0$ \\
Ammonium monohydrogen phosphate & $1782.5 \pm 0.0$ \\
\hline
\end{tabular}


Table 5. Relation of different inocula sizes, different incubation periods and vitamins to protease(s) productivity by $B$. licheniformis B-42 allowed to grow under SmF conditions at $55 \circ \mathrm{C}$ for $48 \mathrm{~h}$.

\begin{tabular}{|c|c|c|c|c|c|}
\hline $\begin{array}{c}\text { Inoculum } \\
\text { size (ml). }\end{array}$ & $\begin{array}{c}\text { Protease(s) } \\
\text { Production } \\
\mathbf{( U / m l )}\end{array}$ & $\begin{array}{c}\text { Incubation } \\
\text { Period } \\
\text { (hours) }\end{array}$ & $\begin{array}{c}\text { Protease(s) } \\
\text { Production } \\
\mathbf{( U / m l )}\end{array}$ & Vitamin & $\begin{array}{c}\text { Protease(s) } \\
\text { Production } \\
\text { (U/ml) }\end{array}$ \\
\hline 0.1 & $100.23 \pm 1.04$ & 6 & $751.67 \pm 0.79$ & Control & $17825.01 \pm 0.0$ \\
0.2 & $447.74 \pm 1.04$ & 12 & $1336.69 \pm 0.52$ & Ascorbic acid & $23770.0 \pm 0.79$ \\
0.4 & $597.07 \pm 0.9$ & 24 & $2377 \pm 0.52$ & Nicotinic acid & $23770.0 \pm 1.3$ \\
0.5 & $1888.12 \pm 1.04$ & 48 & $2825.07 \pm 0.38$ & Thiamine $\left(\mathrm{B}_{1}\right)$ & $25178.5 \pm 0.93$ \\
1 & $1002.37 \pm 1.04$ & 72 & $3556.5 \pm 0.42$ & Pyridoxin & $10023.7 \pm 0.98$ \\
1.5 & $1002.37 \pm 0.0$ & 96 & $2825.07 \pm 0.75$ & Riboflavin & $13366.87 \pm 0.52$ \\
2 & $316.98 \pm 1.04$ & 120 & $1336.69 \pm 0.71$ & Folic acid & $7096.26 \pm 0.0$ \\
2.5 & $178.25 \pm 0.0$ & 144 & $316.98 \pm 1.04$ & & \\
5 & $1336.69 \pm 0.52$ & & & & \\
10 & $56.36 \pm 0.0$ & & & & \\
\hline
\end{tabular}

Table 6. Relation of different amino acids application to protease(s) productivity by B. licheniformis B-50 allowed to grow on SHW under semi solid fermentation conditions at $55^{\circ} \mathrm{C}$.

\begin{tabular}{|c|c|c|}
\hline Side chain (SC). & Amino acid. & Protease(s) production (U/ml). \\
\hline \multicolumn{2}{|l|}{ Control } & $1336.7 \pm 0.52$ \\
\hline Aliphatic SC & $\begin{array}{l}\text { Glycine } \\
\text { DL-Alanine } \\
\text { DL-Valin } \\
\text { L-Leucine } \\
\text { DL-Isoleucine }\end{array}$ & $\begin{array}{c}316.98 \pm 0.24 \\
316.98 \pm 0.0 \\
1336.69 \pm 0.52 \\
237.7 \pm 0.52 \\
422.69 \pm 0.52\end{array}$ \\
\hline $\begin{array}{l}\text { Hydroxylic }(\mathrm{OH}) \text { Group- } \\
\text { containing SC }\end{array}$ & $\begin{array}{l}\text { DL-Serine } \\
\text { DL-Threonine } \\
\text { DL-Tyrosine }\end{array}$ & $\begin{array}{ll}2118.5 \pm & 0.49 \\
751.67 \pm & 0.52 \\
751.67 \pm & 0.52 \\
\end{array}$ \\
\hline $\begin{array}{l}\text { Sulphur atom- } \\
\text { containing SC }\end{array}$ & $\begin{array}{l}\text { L-Cystein } \\
\text { L- Methionine }\end{array}$ & $\begin{array}{c}316.98 \pm 0.0 \\
1002.37 \pm 1.04\end{array}$ \\
\hline Acidic groupes or their amides & $\begin{array}{l}\text { DL-Aspartic acid } \\
\text { L-Glutamine }\end{array}$ & $\begin{array}{l}1002.37 \pm 0.52 \\
1888.12 \pm 1.2 \\
\end{array}$ \\
\hline Basic group & $\begin{array}{l}\text { L-Arginine } \\
\text { L-Lysine } \\
\text { L- Histidine }\end{array}$ & $\begin{array}{c}2377.0 \pm 0.52 \\
563.68 \pm 0.0 \\
1002.37 \pm 1.04\end{array}$ \\
\hline Aromatic group & $\begin{array}{l}\text { L -Phenylalanine } \\
\text { Tryptophan }\end{array}$ & $\begin{array}{l}893.36 \pm 0.38 \\
1336.69 \pm 0.52 \\
\end{array}$ \\
\hline Imino group & L- Proline & $316.98 \pm 0.0$ \\
\hline
\end{tabular}


Table 7. A summary of the optimal nutritional and environmental parameters controlling of protease productivities by $B$. licheniformis EGT50 under solid state fermentation conditions

\begin{tabular}{|l|c|l|c|}
\hline \multicolumn{1}{|c|}{ Parameter } & B. licheniformis B42 & \multicolumn{1}{|c|}{ Parameter } & B. licheniformis B42 \\
\hline Temperature $\left({ }^{\circ} \mathrm{C}\right)$ & 55 & Inoculum size $(\mathrm{ml})$ & 0.5 \\
pH value & 9 & Incubation period (hour) & 72 \\
Substrate concentration & 1.5 & Amino acid & Argenine \\
Carbon source & Galactose & Bottle capacity (ml) & 1000 \\
Nitrogen source & $\left(\mathrm{NH}_{4}\right)_{2} \mathrm{H}_{2} \mathrm{PO}_{4}$ & & \\
\hline
\end{tabular}

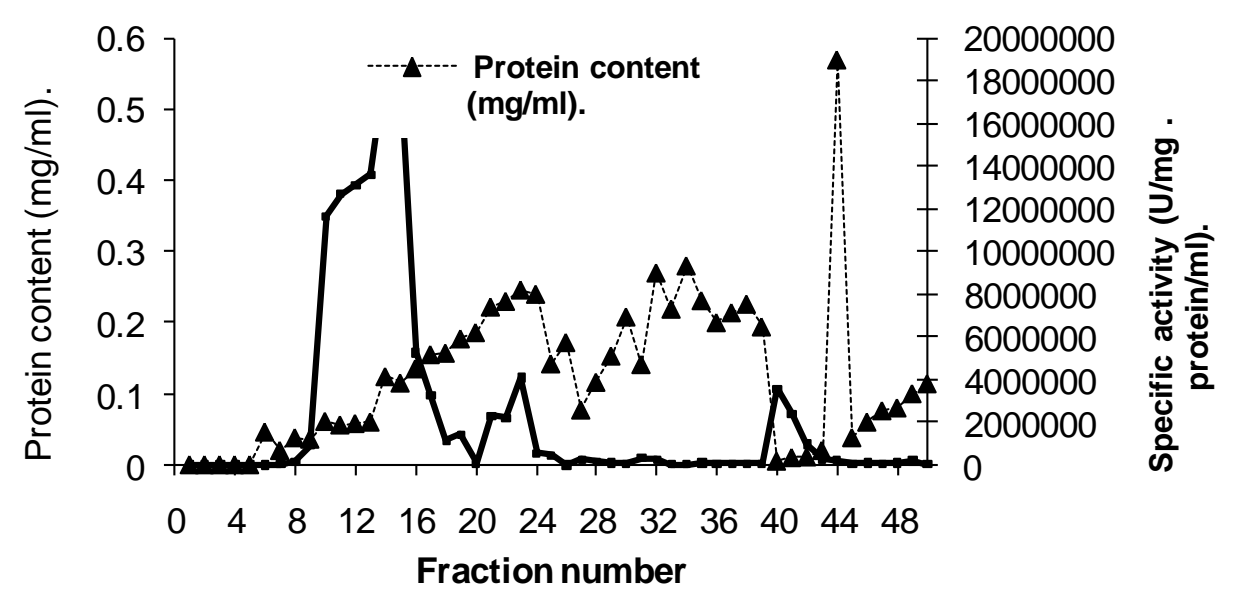

Fig. 2. Fractionation pattern of protease(s) produced by $B$. licheniformis B-42 at $55^{\circ} \mathrm{C}$ using sephadex G-200 column chromatography technique.

Table 8. A summary of the purification steps of protease produced by $B$. licheniformis EGT50 allowed to grow on SHW substrate at 55ㄷ under SmF

\begin{tabular}{|c|c|c|c|c|c|c|c|c|}
\hline $\begin{array}{l}\text { Purification } \\
\text { step }\end{array}$ & $\begin{array}{c}\text { Volume } \\
\text { (ml) }\end{array}$ & $\begin{array}{c}\text { Protein } \\
\text { concentration } \\
(\mathrm{mg} / \mathrm{ml})\end{array}$ & $\begin{array}{c}\text { Total } \\
\text { protein } \\
(\mathrm{mg} / \mathrm{ml})\end{array}$ & $\begin{array}{c}\text { Protease } \\
\text { activity } \\
(\mathrm{U} / \mathrm{ml})\end{array}$ & $\begin{array}{c}\text { Total } \\
\text { activity }\end{array}$ & $\begin{array}{c}\text { Specific } \\
\text { activity } \\
\text { (U/mg, } \\
\text { protein) }\end{array}$ & $\begin{array}{l}\text { Purification } \\
\text { fold }\end{array}$ & $\begin{array}{l}\text { Yield } \\
(\%)\end{array}$ \\
\hline CFF & 1140 & 0.38 & 433.2 & 17825.01 & 20320510.94 & 46907.92 & 1 & 100 \\
\hline $\begin{array}{l}\text { Ammonium } \\
\text { sulphate }\end{array}$ & 100 & 0.965 & 96.5 & 2000000 & 200000000 & 2072538.86 & 44 & 980 \\
\hline $\begin{array}{l}\text { Dialysis against } \\
\text { sucrose }\end{array}$ & 4.5 & 1.1 & 4.95 & 5636765.86 & 25365446.37 & 5124332.6 & 109.24 & 124 \\
\hline Sephdex G-200 & 5.0 & 0.124 & 0.62 & 2296307.24 & 11481536.2 & 18518606.7 & 394.7 & 56 \\
\hline
\end{tabular}


Data recorded in Table (7) showed a summary of the optimal nutritional and physicho-chemical conditions for alkaline thermostable protease production by $B$. licheniformis EGT50 grown on SHW as preferable substrates.

\subsection{Partial purification of the alkaline thermo- stable enzyme and its kinetic characteriza- tion}

The application in the bio-detergent industry does not require highly-pure alkaline thermostable protease and generally makes use of crude or partially purified preparations are valid. However, it is significant to obtain enzymes with higher specific activity for their kinetic characterization. Traditionally, the purification of alkaline thermostable proteases from fermentation media has been done in several steps which include centrifugation of culture filtrate, selective precipitation of the enzyme by ammonium sulphate, followed by gel filtration (Pandey et al 2001; Mário et al 2009 and Haddar et al 2010).

An attempt to purify alkaline thermostable protease from $B$. licheniformis EGT50 partially, the cell free filtrate supernatant was subjected to ammonium sulphate precipitation, gel filtration on Sephadex G200 columns chromatography. B. licheniformis EGT50 was allowed to grow on the production medium under all optimal semisolid fermentation conditions as shown in Table (7) for the production of alkaline thermostable protease. At the end of incubation period, $1000 \mathrm{ml}$ of protease(s) was extracted. Results presented in Figure (2) showed that three active peaks were obtained after purification of protease(s) by applying sephadex G200 column chromatography in fractions (9-18), fractions (21-26), fractions (39-42) and the fraction 14 reached the highest specific activity up to $18518606.7 \mathrm{U} / \mathrm{mg}$ protein.

A summary of the purification steps of protease produced by $B$. licheniformis EGT50 was presented in Table (8). The alkaline thermostable enzyme was partially purified 394.7 folds with sephadex G200.

\section{Conclusion}

Bacillus licheniformis was isolated from soil samples collected from different localities of El-Khorma Governorate,Taif, kingdom of Saudi Arabia (KSA). and the organism was studied for the production of thermoalkaliphilic protease under different environ- mental and nutritional requirements on cheap raw material viz. slaughter house wastes (SHW). This enzyme was found to have ability to stability at high temperature and alkaline $\mathrm{pH}$ is useful for many industrial processes especially in biodetergent industry.

\section{REFERENCES}

Abidi, F.; F. Liamam and M.M. Nejib. (2008). Production of alkaline proteases by Botrytis cinerea using economic raw materials. Assay as biodetergent. Proc. Biochem. 43: 12021208.

Akanbi, T.O.; A.L. Kamaruzaman; F. Abu Bakar; N. Sheikh Abdul Hamid; S. Radu; M.Y. Abdul Manap and N. Saari. (2010). Highly thermostable extracellular lipase-producing Bacillus strain isolated from a Malaysian hotspring and identified using 16S rRNA gene sequencing. Inter. Food Res. J. 17: 45-53.

Amara, A.A.; Soheir R. Salem and M.A. Shabeb (2009). The Possibility to use bacterial protease and lipase as biodetergent. Global J. of Biotechnol. \& Biochem. 4(2): 104-114.

Ammar, M.S.; M.S. El-Gamal; S.S. El-Louboudy and A.M. Ibrahim. (1991): Constitutive bacterial protease(s) produced under natural solid state fermentation in the open air. Az. J. Microbiol. 13, 176-195.

Babu, K.R. and T. Satyanarayana. (1995). aAmylase production by thermophilic Bacillus coagulans in solid state fermentation. Process Biochem., 30: 305-309.

Barrow, G.I. and R.K. Feltham. (1993). Cowan \& Steel: Manual for the Identification of Medical Bacteria. $2^{\text {nd }}$ Ed. Cambridge Univ. Press. London.

Beg, Q. and R. Gupta. (2003): Purification and characterization of an oxidation stable, thioldependent serine alkaline protease from Bacillus mojavensis. Enzyme and Microbial Technol. 32: 294-304.

Christiansen, T. and J. Nielsen. (2002). Growth energetics of an alkaline serine proteaseproducing strain of Bacillus clausii during continuous cultivation. Bioprocess Biosystem Eng. 24: 329-339.

Cowan, D. (1996). Industrial enzyme technology. Trends Biotechnol., 14(6): 177-178.

Eltayib, H.A.; T. Raghavendra and D. Madamwar. (2010). A thermostable alkaline lipase from a local isolate Bacillus subtilis EH37: Characterization, partial purification and application in organic synthesis. Appl. Biochem. \& Biotechnol. 160(7): 2101-2113. 
Gupta, R.; Q. Beg; S. Khan and B. Chauhan. (2002). An overview on fermentation, downstream processing and properties of microbial alkaline proteases. Appl. Microbiol. Biotechnol. 60: 381-395.

Haddar, Anisa C.; Alya A. Sellami-Kamoun; Nahed F. Nedra; H. Noomen and N. Moncef (2010). Characterization of detergent stable and feather degrading serine proteases from Bacillus mojavensis A21. Biochem. Engin. J. 51(1-2): 53-63.

Hensyl, W.R. (1994). Bergey's Manual of Determinative Bacteriology $9^{\text {th }}$ Edition, pp. 527558. Williams \& Wilkins, Baltimore.

Joo, H.S.; C.G. Kumar; G.C. Park; S.R. Paik and C.S. Chang. (2003). Oxidant and SDS-stable alkaline protease from Bacillus clausii 1-52: Production and some properties. J. Appl. Microbiol. 95: 267-272.

Joo, H.S.; C.G. Kumar; G.C. Park; S.R. Paik and C.S. Chang. (2004). Bleach-resistant alkaline protease produced by a Bacillus sp. isolated from the Korean polychaeta. Periserrula leucophryna. Process Biochem. 39: 1441-1447.

Kumar, C.G.; M.P. Tiwari and K.D. Lany. (1999). Novel alkaline serine proteases from alkalophilic Bacillus spp: Purification and some properties. Process Biochem. 34: 441-449.

Kumar, G.; H. Joo; Y. Koo; S. Paik; P. Parkack and C. Chang. (2004). Thermostable alkaline protease from a novel marine haloalkalophilic Bacillus clauseii. World J. Microbiol. Biotechnol. 20: 351-357.

Kumar, M.S.; C.M. Karrunakaran and S. Anbuselvi. (2009). Production of lipase from Bacillus spp. using germinated maize oil and various carbon sources and effect of lipase activity on $\mathrm{pH}$ and temperature. Inter. J. Biotechnol. \& Biochem. 5(4): 2210-2220.

Leuschner, C. and G. Antranikan. (1995). Heat stable enzymes from extremely thermophilic and hyperthermophilic microorganisms. World J. Microbiol. Biotechnol., 11: 95-114.

Lowry, O.H.; N.G. Rosebrough; A.L. Farr and R. J. Randall. (1951). Protein measurement with the Folin-Phenol reagent. J. Bio. Chem., 193: 265-275.

Mário. L.T.; C. Florencia; S. Juliana and B. Adriano. (2009). Purification and characterization of a peptide from Bacillus licheniformis showing dual antimicrobial and emulsifying activities. Food Research International. 42(1): 63-68.

Nunes, A.S. and M.L. Martins. (2001). Isolation, properties and kinetics of growth of thermophilic Bacillus. Braz. J. Microbiol., 32:271275.
Pandey, A.; C. Soccol and D. Mitchell. (2000). New developments in solid state fermentation. I: Bioproeess, and products. Proc Biochcm 35: 1153-1169.

Pandey, A; C.R. Soccol; J.A. Rodriguez-Leon and P. Nigam. (2001). History and development of solid state fermentation. In: Pandey, A. Editor. Solid State Fermentation in Biotechnology: Fundamentals and Applications. pp.3-7. New Delhi: Asiatech Publishers.

Pandey, A.; P. Selvakumar; C.R. Soccal and P. Nigam. (1999). Solid state fermentation for the production of industrial applications. Appl. Biochem. Biotechnol. 8: 35-52.

Pandey, A.; P. Selvakumar; C.R. Soccal; U.T. Soccal; N. Krieger and J.D. Fontana. (1999). Recent development in microbial inulinasesits production, properties and industrial application. Enzyme Microb. Technol., 7: 258265.

Rao, M.; A. Tankasale; M. Ghatge and V. Desphande. (1998). Molecular and biotechnological aspects of microbial proteases. Microbiol. Mol. Biol. Rev., 62: 597-634.

Schäfer, T.; O. Kirk; T.V. Borchert; C.C. Fuglsang; S. Pedersen; S. Salmon; H.S. OIsen; R. Deinhammer and H. Lund. (2005). Enzymes for Technical Applications. In: Biopolymers, Chapter 13, pp. 377-437, Fahnestock, S.R. and A. Steinbüchel, Wiley VCH Editor, N.Y.

Schallmey, M.; A. Singh and W.P. Ward. (2004). Developments in the use of Bacillus species for industrial production. Can. J. Micrbiol. 50: 1-17.

Sneath, P.H.A.; N.S. Mair; M.F. Sharpe and J.G. Holt. (1986). Bergey's Manual of Systematic Bacteriology. Williams \&Wilkins, Baltimore.

St. Leger, R.J.; J.O. Nelson and S.F. Screen. (1999). The entomo-pathogenic fungus $\mathrm{Me}$ tarhizium anisopliae alters ambient $\mathrm{pH}$, allowing extracellular protease production and activity. Microbiology., 145(10): 2691-2699.

Tongerdy, R.P. (1998). Solid substrate fermentation for enzyme production. In: Pandey, editor. Advances In Biotechnology. pp. 13-16. Educational Publishers and Distributors, New Delhi.

Vincent, J.M. (1970). A Manual for The Practical Study of the Root Nodule Bacteria. p. 75. International Biological Program. Blackwell Scientific Publications, Oxford.

Yang, J.K.; T.L. Shih; Y.M. Tzeng and S.L. Wang. (2000). Production and purification of protease from a Bacillus subtilis that can deproteinize crustacean wastes. Enz. and Microbiol. Technol. 26: 406-413. 